\title{
СТАНДАРТИ ПСИХОЛОГО-ПЕДАГОГІЧНОЇ ПІДГОТОВКИ ВЧИТЕЛІВ ЗАКЛАДІВ ЗАГАЛЬНОЇ СЕРЕДНЬОЇ ОСВІТИ В НІМЕЧЧИНІ
}

\begin{abstract}
Анотація. Проаналізовано стандарти психолого-педагогічної підготовки вчителів закладів загальної середньої освіти в Німеччині та виявлено ключові принципами структурування змісту їхньої психолого-педагогічної підготовки в університетах досліджуваної країни. Для досягнення мети дослідження було застосовано такі методи: загальнонаукові (аналіз, синтез, узагальнення), з допомогою яких відбувалось опрацювання нормативно-правової бази забезпечення професійної підготовки учителів закладів загальної середньої освіти у ФРН та програмно-методичної документації німецьких університетів; структурно-функціонального аналізу, на основі якого було виявлено підходи до структурування змісту психолого-педагогічної підготовки вчителів в університетах ФРН. Під час дослідження з'ясовано, що підготовка майбутніх учителів закладів загальної середньої освіти в університетах Німеччини включає чотири блоки: 1) спеціально-предметний; 2) предметно-дидактичний; 3) «Науки про освіту»; 4) професійно-педагогічна практика. Підкреслено особливе значення блоку «Науки про освіту», оскільки він відображає зміст психолого-педагогічної підготовки вчителів. Виявлено, що стандарти підготовки вчителів за блоком «Науки про освіту» сформульовані з огляду компетентностей, якими повинен оволодіти майбутній учитель для ефективної реалізації професійно-педагогічної діяльності. Зроблено ряд висновків: 1) впровадження стандартів $\epsilon$ основним інструментом реформування професійної педагогічної освіти у ФРН на початку ХХІ століття; 2) розроблення стандартів підготовки майбутніх учителів здійснюється з орієнтуванням на результат - розвиток професійних компетентностей, оновою яких $є$ міждисциплінарні знання та рефлексія набутого досвіду; 3) стандарти є динамічною сукупністю вимог до підготовки вчителя, що можуть доповнюватися і змінюватися залежно від соціально-культурних умов професійної педагогічної діяльності; 4) стандарти спрямовані не на індивідуальну діяльність учителя, а на його цілісний професійний розвиток з урахуванням участі у розвитку школи; 5) стандарти є рамковою структурою для подальшої розробки курікулуму та формування змісту модулів психологопедагогічної підготовки майбутніх учителів; 6) ключовими принципами структурування змісту психолого-педагогічної підготовки вчителів закладів загальної середньої освіти відповідно до вищезгаданих стандартів є такі: міждисциплінарності, модульності, рефлективності.

Ключові слова: стандарти підготовки вчителів, психолого-педагогічна підготовка, науки про освіту, курікулум, майбутні вчителі, заклад загальної середньої освіти, Федеративна Республіка Німеччина (ФРН).
\end{abstract}

\section{STANDARDS OF PSYCHOLOGICAL AND PEDAGOGICAL TEACHERS TRAINING IN GERMANY}

Abstract. The standards of psychological and pedagogical training of teachers of general secondary education institutions in Germany are analyzed and the key principles of structuring the content of their psychological and pedagogical training in the universities of the studied country are identified. To achieve the goal of the study, the following methods were used: general scientific (analysis, synthesis, generalization), which were used to develop the legal framework for professional training of teachers of general secondary education in Germany and program-methodological documentation of German universities; structural and functional analysis, based on which approaches to structuring the content of psychological and pedagogical training of teachers in universities of Germany were identified. The study found that the training of future teachers of general secondary education in German universities includes four blocks: 1) special-subject; 2) subject-didactic; 3) "Science of Education»; 4) professional and pedagogical practice. The special importance of the block "Science of Education» is emphasized, as it reflects the content of psychological and pedagogical training of teachers. It was found that the standards of teacher training in the block «Science of Education» are formulated in view of the competencies that must be mastered by the future teacher for the effective implementation of professional and pedagogical activities. A number of conclusions have been made: 1) the introduction of standards is the main tool for reforming professional pedagogical education in Germany at the beginning of the XXI century; 2) the development of standards for the training of future teachers is carried out with a focus on results - the development of professional competencies, the new of which is interdisciplinary knowledge and reflection on experience; 3) standards are a dynamic set of re- 
quirements for teacher training, which can be supplemented and changed depending on the socio-cultural conditions of professional pedagogical activity; 4) standards are aimed not at the individual activities of the teacher, but at his holistic professional development, taking into account participation in school development; 5) standards are a framework structure for further development of the curriculum and the formation of the content of modules of psychological and pedagogical training of future teachers; 6) the key principles of structuring the content of psychological and pedagogical training of teachers of general secondary education in accordance with the above standards are as follows: interdisciplinarity, modularity, reflectivity.

Key words: standards of teacher training, psychological and pedagogical training, psychological and pedagogical training, sciences about education, curriculum, future teachers, secondary school, Federal Republic of Germany.

Вступ. Початок XXI століття ознаменувався не лише стрімкими соціальноекономічними і політичними змінами в суспільстві, а й переосмисленням ролі вчителя в умовах розвитку глобалізаційних та інтеграційних процесів. $\mathrm{y}$ міжнародних правових актах (документи ЮНЕСКО, Організації економічного співробітництва та розвитку (ОЕСР), Ради Європи а інші) зазначено, що саме потенціал учительського корпусу $є$ основою забезпечення високої якості та конкурентоспроможності освіти на світовому ринку праці, а вчитель XXI століття проголошений носієм суспільних змін.

На особливому значенні підготовки педагогічних працівників, які $\epsilon$ основною рушійною силою оновлення національної системи освіти відповідно до вимог сучасносTi, наголошено також у ключових українських документах, таких як: Закон України «Про освіту» (2017), Національна стратегія розвитку освіти в Україні на період до 2021 року (2013), Концепція реалізації державної політики у сфері реформування загальної середньої освіти «Нова українська школа» на період до 2029 року (2016), розпорядження Кабінету Міністрів України «Про додаткові заходи щодо підвищення кваліфікації педагогічних працівників у 2018 році» (2018), Концепція розвитку педагогічної освіти (2018), галузева Концепція розвитку неперервної педагогічної освіти (2013). Зокрема серед стратегічних напрямів розвитку освіти задекларовано необхідність модернізації структури, змісту та організації освіти на засадах компетентнісного підходу, що переносить акценти 3 процесу накопичення нормативно визначених знань, умінь і навичок в площину формування й розвитку здатності практично діяти і творчо застосовувати набуті знання і досвід у різних ситуаціях. У такій концептуальній схемі психолого-педагогічна підготовка майбутнього вчителя повин- на бути діяльнісно і особистісно орієнтованою, оскільки компетентності розвиваються і виявляються в діяльності за умови глибокого особистісного зацікавлення, та на основі комплексних міждисциплінарних знань, зорієнтованих на розв'язання проблем практичної педагогічної діяльності. Це, безумовно, актуалізує потребу оновлення змісту та пошуку ефективних форм і методів психолого-педагогічної підготовки майбутніх учителів у закладах вищої освіти.

У контексті зазначеного, досвід стандартизації психолого-педагогічної підготовки вчителів закладів загальної середньої освіти у Федеративній Республіці Німеччина (ФРН) відкриває нові можливості для удосконалення педагогічної освіти в Україні в умовах іiї адаптації до вимог загальноєвропейського освітнього простору. Інтерес до системи вищої педагогічної освіти у ФРН зумовлений низкою причин, зокрема: ця країна має багаті історичні традиції освіти, що дає їй змогу відігравати провідну роль у галузі світової науки і освіти; вона $є$ однією з найбільш розвинених і відкритих країн Європи; Німеччина є однією $з$ країн-ініціаторів та активним учасником процесу створення європейського простору вищої освіти і має значний досвід у галузі професійної підготовки фахівців у нових соціокультурних умовах.

Мета статті - проаналізувати стандарти психолого-педагогічної підготовки вчителів закладів загальної середньої освіти в Німеччині та виявити ключові принципами структурування змісту їхньої психологопедагогічної підготовки в університетах досліджуваної країни.

Теоретична основа i методи дослідження. За роки незалежності нашої держави посилився інтерес дослідниківкомпаративістів до вивчення системи освіти у ФРН. Різні аспекти німецької моделі підготовки педагогічних кадрів досліджу- 
вали Л. Пуховська, Б. Мельниченко, Н. Махиня, С. Бобраков, Т. Вакуленко та інші. Водночас, аналіз вітчизняної наукової літератури показав, що психолого-педагогічна підготовка вчителів загальноосвітніх шкіл у ФРН не була предметом системного наукового пошуку в Україні й досліджена недостатньо.

Важливими для нашого дослідження стали наукові доробки німецьких вчених щодо окремих аспектів підготовки майбутніх учителів закладів загальної середньої освіти. Зокрема такі науковці, як: Е. Терхарт (Terhart, 2000), Й. Шютценмайстер (Schützenmeister, 2002) у своїх працях проаналізували стан та проблеми професійної педагогічної підготовки учителів загальноосвітніх шкіл у ФРН на початку XXI століття; К. Бауер (Bauer, 2005), Ю. Баумерт (Baumert, 2011), В. Ніке (Nieke, 2006) обгрунтували структуру професійної компетентності вчителів у ФРН.

Вищезгадані німецькі науковці у своїх працях актуалізують такі проблеми підготовки вчителів: недостатня професійна спрямованість; брак зв'язків між наукою і практикою; недостатня увага до вивчення методики викладання предмету; відсутність взаємодії між фазами університетської підготовки, стажуванням та подальшим професійним розвитком учителів; недостатня увага особистісного зростання фахівцяпедагога. Особливо вони підкреслюють потребу оновлення змісту психологопедагогічної підготовки вчителів як основи розвитку професійної компетентності майбутнього фахівця-педагога.

У контексті теми дослідження важливим, на нашу думку, є розгляд стандартів підготовки вчителів за блоком «Науки про освіту», оскільки на їхній основі відбувається структурування змісту психологопедагогічної підготовки майбутніх учителів закладів загальної середньої освіти усіх типів. Нами виявлено, що їхнє створення і впродження викликали хвилю дискусій серед німецьких науковців, до якої долучились К. Бек (Beck, 2006), М. Бранденберг (Brandenberg, 2002), В. Герцог (Herzog, 2005), Л. Кіблец (Ciblez, 2003), Е. Кліме (Klieme, 2006), Й. Майр (Mayr, 2013), Ю. Олькерс (Oelkers, 2003), C. Pex (Reh, 2002), Е. Терхарт (Therhart, 2005), М. Фухс i
М. Цутаверн (Fuchs \& Zutavern, 2003) та іншi.

Позитивне значення вищезгаданих стандартів для підвищення якості підготовки вчителів підкреслили у своїх працях такі науковці: Ю. Олькерс (Oelkers, 2003), керівник робочої групи з розвитку стандартів підготовки вчителів Міністерства освіти, науки і культури федеральної землі Рейнланд-Пфальц, Е. Терхарт (Therhart, 2005), керівник робочої групи з розвитку стандартів «Науки про освіту» Конференції міністрів освіти і культури, Е. Кліме (Klieme, 2006), розробник національних освітніх стандартів у ФРН, директор департаменту «Оцінки якості освіти» Німецького інституту міжнародних досліджень у галузі освіти (Франкфурт на Майні) та інші.

Водночас, затверджені стандарти отримали ряд критичних зауважень. В. Герцог (Herzog, 2005), професор Цюріхського університету, висловив критику щодо їх теоретичного обгрунтування та структурної єдності (c. 253). C. Pex (Reh, 2002), науковий співробітник Німецького інституту міжнародних досліджень у галузі освіти (Франкфурт на Майні), звернув увагу на коректність їх формулювання, підкресливши, що затверджені стандарти не відображають наукову основу професійної педагогічної діяльності (с. 259).

Процеси стандартизації педагогічної освіти у різних країнах світу, у тому числі в Німеччині, стали предметом досліджень українських компаративістів. Професор Л. Пуховська (2013) у статті «Стандарти педагогічної освіти: наукова дискусія західних учених» зазначає, що розбудова світового і європейського освітнього простору, гармонізація національних систем освіти, зокрема педагогічної, в умовах розвитку ринку освітніх послуг актуалізують проблеми еквівалентності кваліфікацій, навчальних курсів, дипломів, свідоцтв тощо. А це, у свою чергу, породжує стрімкі процеси стандартизації педагогічної освіти (с. 10).

Л. Пуховська (2013) актуалізує увагу на тому, що наявність стандартів в дійсності не гарантує якості педагогічної освіти, оскільки особливість їх інтерпретації і запровадження пов'язана з людським фактором. Дослідниця приєднується до думки вчених, які вважають професійні стандарти 
вчителя інструментом реалізації стратегії освіти у стрімкозмінному світі (с. 17).

Інша українська дослідниця-компаративіст професор О. Локшина (2009) наголошує на тому, що в країнах західної $\epsilon_{\text {в- }}$ ропи відбувається відхід від усталеної практики структурування змісту на основі предметного принципу, який передбачає відповідність структури змісту освіти структурі галузей наукових знань. За компетентнісного підходу зміст освіти визначається не шляхом конкретизації кількості навчальних предметів (так зване «регулювання входу»), а через визначення результатів («регулювання виходу»), які планується отримати на національному рівні (c. 19). Саме такий підхід відображено у німецьких стандартах підготовки вчителів за блоком «Науки про освіту».

Для досягнення мети дослідження було застосовано такі методи: загальнонаукові (аналіз, синтез, узагальнення), з допомогою яких відбувалось опрацювання нормативно-правової бази забезпечення професійної підготовки учителів закладів загальної середньої освіти у ФРН та програмнометодичної документації німецьких університетів; структурно-функціонального аналізу, на основі якого було виявлено підходи до структурування змісту психологопедагогічної підготовки вчителів в університетах ФРН.

Виклад основного матеріалу. Нами виявлено, що в основу стандартів психолого-педагогічної підготовки вчителів закладів загальної середньої освіти в Німеччині покладено завдання сучасного вчителя, розкриті у спільній заяві Президента Конференції міністрів освіти і культури федеральних земель, голови профспілки працівників освіти і голови професійного об'єднання вчителів (Постанова Конференції міністрів освіти і культури федеральних земель від 5 жовтня 2000 р.). Стисло окреслимо ці завдання.

1. Учителі $\epsilon$ експертами у сфері навчання і викладання. Їх основним завданням $\epsilon$ цілеспрямоване науково обгрунтоване планування, організація, проведення і аналіз, індивідуальне і систематичне оцінювання процесів навчання і учіння. Професійні якості вчителя визначають якість навчальних занять.
2. Учителі усвідомлюють, що освітні завдання школи реалізуються на щоденних заняттях та у процесі шкільного життя. Ефективність їх виконання залежить також від співпраці вчителя з батьками. Обидві сторони повинні співпрацювати та спільно шукати конструктивні рішення у випадку ускладнень у навчально-виховному процеci.

3. Учителі справедливо, відповідально та неупереджено здійснюють діагностику, оцінювання та аналіз під час занять та проводять подальшу профорієнтацію. Для цього педагогічний персонал повинен мати високий рівень педагогічної, психологічної та діагностичної компетентностей.

4. Учителі постійно розвивають власну компетентність не лише у галузі педагогіки, а й у інших сферах для того, щоб враховувати найновіші наукові досягнення у своїй щоденній роботі. Для цього вчителі підтримують контакти з різними установами та організаціями.

5. Учителі долучаються до розвитку школи, сприяють формуванню шкільної культури, розвитку навчальної мотивації учнів, налагодженню сприятливого емоційного клімату. Це включає також готовність до участі у внутрішкільних і позашкільних заходах (Kultusministerkonferenz, 2000 , c. 2-5; Kultusministerkonferenz, 2004, 2014, c. 3).

Ці завдання знайшли своє логічне відображення у змісті професійних компетентностей учителів, що описані у стандартах їх психолого-педагогічної підготовки. Їх ми і розглянемо далі.

Конференція міністрів освіти і культури своєю основною метою визначає підвищення якості підготовки підростаючого покоління, для успішної реалізації якої, в першу чергу, необхідно забезпечити якісну підготовку педагогічного персоналу, зокрема учителів. 3 метою професіоналізації та підвищення якості підготовки вчителів закладів загальної середньої освіти Конференцією міністрів освіти і культури 16 грудня 2004 року було затверджено стандарти підготовки вчителів за блоком «Науки про освіту» (Kultusministerkonferenz, 2004, 2014, c. 2).

Стандарти визначені через компетентності, якими повинен оволодіти майбутній учитель для ефективної реалізації щоден- 
ної професійної педагогічної діяльності за чотирма галузями: навчання, виховання, оцінювання, інновації. Особливого значення набуває удосконалення набутих компетентностей у процесі подальшої освіти, оскільки розвиток компетентностей - це процес динамічний і неперервний.

У стандартах сформульовано загальну мету навчання, цілі викладання груп навчальних предметів і керівні принципи для планування й конструювання курікулуму регіональними і місцевими органами, університетами. Підкреслено, що блок «Науки про освіту» $\epsilon$ міждисциплінарним і охоплює ряд наукових дисциплін (педагогіка, психологія, соціологія), які роз'яснюють процеси освіти і виховання, розкривають основи функціонування освітніх систем, їхні внутрішні і зовнішні взаємозв'язки (Kultusministerkonferenz, 2004, 2014, c. 2).

Стандарти є рамковою структурою для подальшої розробки курікулуму та формування змісту модулів психологопедагогічної підготовки. Курикулум є рамковою основою змісту навчання в системі вищої та післядипломної освіти (Національна академія педагогічних наук України, 2017 , с. 25). Курикулум як документ відрізняється від навчальної програми, що визначає, в першу чергу, змістовну сторону курсу навчання і складає лише частину курикулуму. Крім програми, курикулум містить аналіз причин необхідності впровадження нового змісту освіти; чітке визначення цілей навчання; окреслення цільових груп, на які розрахований даний курикулум; опис передбачуваних взаємин вчителя і тих, кого навчають, узгодженість методичних принципів з відповідними навчальними матеріалами; сучасні моделі і засоби навчання; систему і принципи контролю і оцінки (Біла книга національної освіти, 2009, с. 50).

Центральними пунктами курікулуму підготовки учителів закладів загальної середньої освіти за блоком «Науки про освіту» у стандартах визначено такі: освіта і виховання; професія і роль учителя; стратегії дій у ситуаціях прийняття рішень; проєктування навчального процесу і навчального середовища; навчання, розвиток, соціалізація; мотивація успіху та навчальна мотивація; диференціація, інтеграція, підтримка; діагностика, оцінювання, консуль- тування; комунікація, взаємодія та керування конфліктами; медіаосвіта та медіаграмотність; розвиток школи; дослідження в галузі освіти. У стандартах наголошено на особливому значенні підготовки вчителів закладів загальної середньої освіти усіх типів до взаємодії у гетерогенних групах здійснення індивідуального супроводу в системі шкільної освіти дітей з обмеженими фізичними і психічними можливостями, обдарованих дітей, мігрантів для забезпечення рівних можливостей і права на навчання на основі принципів гуманізації та індивідуалізації (Kultusministerkonferenz, 2004, 2014, с. 5).

У стандартах немає чіткого переліку дисциплін для вивчення студентами. Натомість визначено ключові теми, які розкривають сферу професійної діяльності вчителя за чотирма галузями - навчання, виховання, оцінюванні, інновації, відповідно до яких визначено компетентності майбутнього вчителя у теоретичному й практичному аспектах університетської підготовки. Подальший розвиток компетентностей забезпечується під час стажування й післядипломної освіти. Зокрема у третьому пункті стандартів описано 11 компетентностей майбутніх учителів, а саме:

1) вчителі професійно і науковообгрунтовано планують і проводять уроки;

2) вчителі підтримують навчальну мотивацію учнів, залучаючи їх до навчальних ситуацій, які дають можливість використовувати здобуті знання й досвід;

3) вчителі сприяють розвитку в учнів здібностей до самостійного навчання й праці;

4) вчителі враховують у навчальновиховному процесі соціальні та культурні умови життя учнів, сприяють їхньому індивідуальному розвиткові;

5) вчителі сприяють формуванню в учнів життєвих цінностей і норм поведінки, заохочують до самостійного прийняття рішень та розробки плану дій;

6) вчителі знаходять оптимальні шляхи вирішення проблемних ситуацій і виходу з конфліктів під час і поза уроку;

7) вчителі здійснюють діагностування умови навчання і навчального процесу, консультують учнів і батьків; 
8) вчителі об'єктивно оцінюють навчальні досягнення учнів на основі прозорих критеріїв;

9) вчителі знають і усвідомлюють вимоги до професії педагога, розуміють свою роботу як державну посаду 3 особливою відповідальністю та зобов'язаннями;

10) вчителі здійснюють неперервний професійний саморозвиток і самовдосконалення;

11) вчителі беруть участь у плануванні й реалізації шкільних проектів з метою розвитку школи (Kultusministerkonferenz, 2004, 2014, c. 7-14).

У стандартах розміщено рекомендації для ефективного розвитку компетентностей і підкреслено, що підготовка майбутніх учителів повинна бути міждисциплінарною, практико і дослідно орієнтованою 3 обов'язковим розвитком професійної рефлексії. Орієнтирами практичної реалізації розвитку професійних компетентностей майбутніх учителів у стандарах визначено такі:

- конкретизація теоретичних концепцій за допомогою вербально описаних прикладів професійної педагогічної діяльності, прикладів з літературних джерел, відеоматеріалів, рольових і ділових ігор, моделювання ситуацій;

- аналіз і методологічна інтерпретація змодельованих, зафільмованих чи безпосередньо спостережуваних навчальних ситуацій;

- ведення відеоспостережень;

- апробація теоретичних концепцій студентами під час практики з подальшою рефлексією досвіду педагогічної діяльності у письмових завданнях, рольових іграх;

- аналіз і рефлексія студентами власного попереднього досвіду навчання на основі теоретичних концепцій;

- використання медіаресурсів у освітньому процесі університету й під час стажування в школі;
- участь студентів у науководослідних проектах;

- співпраця викладачів університету, консультантів центру шкільної практичної підготовки і вчителів школи з метою планування, проведення і аналізу спільних заходів;

- узгодження діяльності осіб, задіяних у супроводі майбутніх учителів під час практики та стажування в школі (Kultusministerkonferenz, 2004, 2014, с. 6).

Висновки. Узагальнюючи розгляд означених стандартів психолого-педагогічної підготовки вчителів закладів загальної середньої освіти в Німеччині, можна зробити ряд висновків:

1) впровадження стандартів $\epsilon$ основним інструментом реформування професійної педагогічної освіти у ФРН на початку XXI століття;

2) розроблення стандартів підготовки майбутнього вчителя здійснюється з орієнтуванням на результат - розвиток професійних компетентностей, оновою яких $\epsilon$ міждисциплінарні знання та рефлексія набутого досвіду;

3) стандарти є динамічною сукупністю вимог до підготовки вчителя, що можуть доповнюватися і змінюватися залежно від соціально-культурних умов професійної педагогічної діяльності;

4) стандарти спрямовані не на індивідуальну діяльність учителя, а на його цілісний професійний розвиток з урахуванням участі у розвитку школи;

5) стандарти $є$ рамковою структурою для подальшої розробки курікулуму та формування змісту модулів психологопедагогічної підготовки майбутніх учителів;

6) ключовими принципами структурування змісту психолого-педагогічної підготовки вчителів закладів загальної середньої освіти відповідно до вищезгаданих стандартів $€$ такі: міждисциплінарності, модульності, рефлективності.

\section{ЛIТЕРАТУРА}

Bauer, K.-0. (2005). Pädagagische Basiskompetenzen. Teorie und Training [Basic pedagogical skills. Theory and training]. Weinheim: Juventa Verlag [in Germany].

Baumert, J. (2011). Professionelle Kompetenz von Lehrkräften: Ergebnisse des Forschungsprogramms COACTIV [Professional competence of teachers: results of the COACTIV research program]. Münster : Waxmann Verlag [in Germany]. 
Beck, K. (2006). Standards - ein Mittel zur Qualitätsentwicklung in der Lehrerbildung [Standards - a means of quality development in teacher education]. Wirtschafts und Erziehung [Economic and Education], 2, 44-45 [in Germany].

Bila knyha natsionalnoi osvity "Syly zmin ta vektory rukhu do novoi osvity Ukrainy» (2009). [The White Book of National Education «Forces of Change and Vectors of Movement for New Education in Ukraine»]. Uporiandyk V. Hromovyi. Kyiv: MBF «Ukraina-3000» [in Ukrainian].

Brandenberg, M. \& Keller, B. (2002). Entwicklung von Standards. Methodisches Vorgehen und Praxiserfahrungen [Development of standards. Methodical approach and practical experience]. Journal für Lehrerinnen- und Lehrerbildung [Journal for teacher training], 2 (1), 61-69 [in Germany].

Ciblez, L. (2003). Standards und/oder Kerncurriculum für die Lehrerbildung? Zur Einführung in den Themen - Schwerpunkt [Standards and / or core curriculum for teacher education? As an introduction to the subject - focus.]. Beitrage zur Lehrerbildung [Contribution to teacher training], 21 (3), 329-333 [in Germany].

Fuchs, M. \& Zutavern, M. (2003). Standards als Möglichkeit zur Professionalisierung [Standards as an opportunity for professionalization]. Beiträge zur Lehrerbildung [Contributions to teacher training], 21 (3), 370-383 [in Germany].

Herzog, W. (2005). Müssen wir Standart wollen? Skepsis gegenüber einem theoretisch (zu) schwachen Konzept [Do we have to want standard? Skepticism about a theoretically weak concept]. Zeitschrift für Pädagogik [Journal of Education], 51 (2), 252-258 [in Germany].

Klieme, E. \& Leutner, D. (2006). Kompetenzmodelle zur Erfassung individueller Lernergebnisse und zur Bilanzierung von Bildungsprozessen [Competence models for recording individual learning outcomes and for accounting for educational processes]. Zeitschrift für Pädagogik [Journal of Education], 52 (6), 876-903 [in Germany].

Kultusministerkonferenz (2000). Gemeinsame Erklärung des Präsidenten der Kultusministerkonferenz und der Vorsitzenden der Bildungs- und Lehrergewerkschaften sowie ihrer Spitzenorganisationen Deutscher Gewerkschaftsbund DGB und DBB - Beamtenbund und Tarifunion (Beschluss der Kultusministerkonferenz vom 5.10.2000). [Joint declaration by the President of the Kultusministerkonferenz and the chairmen of the education and teacher unions as well as their leading organizations, the German Trade Union Federation DGB and DBB] URL: http://www.kmk.org/fileadmin/Dateien/veroeffentlichungen_beschluesse/2000/2000_10_05Aufgaben-Lehrer.pdf [in Germany].

Kultusministerkonferenz (2004, 2014). Standards für die Lehrerbildung: Bildungswissenschaften [Teacher Education Standards: Educational Sciences] (Beschluss der Kultusministerkonferenz vom 16.12.2004 i. d. F. vom 12.06.2014). URL: http://www.kmk.org/fileadmin/veroeffentlichungen beschluesse/2004/2004 12 16-Standards-Lehrerbildung.pdf [in Germany].

Lokshyna, O. I.] (2009). Stanovlennia «kompetentnisnoi» idei v yevropeiskii osviti [Formation of the "competence" idea in European education]. Realizatsiia yevropeiskoho dosvidu kompetentnisnoho pidkhodu u vyshchii shkoli Ukrainy: materialy metodol. seminaru [Implementation of the European experience of the competence approach in the higher school of Ukraine: materials method. seminar]. Київ: Пед. думка, 19-33 [in Ukrainian].

Mayr, J. \& Nieskens, B. (2013). Das Eignungspraktikum - engagierte Lehrkräfte gewinnen [The aptitude internship - attract committed teachers]. Schule NRW: Amtsblatt des Ministeriums für Schule und Weiterbildung des Landes Nordrhein-Westfalen [School NRW: Official Journal of the Ministry for Schools and Further Education of the State of North Rhine-Westphalia], Januar (1), 40-44 [in Germany].

Natsionalna akademiia pedahohichnykh nauk Ukrainy (2017). Kurykulum pidvyshchennia kvalifikatsii pedahohichnykh, naukovo-pedahohichnykh pratsivnykiv ta kerivnykiv zakladiv osvity haluzi znan 01 Pedahohichna osvita: zb. robochykh navchalnykh prohram. [Curriculum for professional development of pedagogical, scientific and pedagogical workers and heads of educational institutions in the field 01 Pedagogical education]. Kyiv: TsIPPO [in Ukrainian].

Nieke, W. (2006). Professionelle pädagogische Handlungskompetenz zwischen Qualifikation und Bildung [Professional pedagogical competence between qualification and education]. Rapold, M. (Hrsg.) [Eds.]. Pädagogische Kompetenz, Identität und Professionalität [Pedagogical competence, identity and professionalism]. Baltmannsweiler: Schneider Verlag Hohendehren, 2006, 35-49 [in Germany].

Oelkers, J. (2003). Standards in der Lehrerbildung. Eine dringliche Aufgabe, die der Präzisierungbedarf [Standards in teacher education. An urgent task that needs to be specified]. Professionalisierung der Lehrerbildung: Zeitschrift für Erziehungswissenschafts, wissenschaft Bildungspolitik und pädagogische Praksis [Professionalization of teacher training: magazine for educational science, scientific education policy and pedagogical practice], 7, 54-70 [in Germany]. 
Pukhovska, L. P. (2013). Standarty pedahohichnoi osvity: naukova dyskusiia zakhidnykh uchenykh [Standards of pedagogical education: scientific discussion of Western scientists]. Tavriiskyi visnyk osvity [Taurian Bulletin of Education], 4 (44), 10-18 [in Ukrainian].

Reh, S. (2002). Die Begründung von Standards in der Lehrerbildung. Theoretische Perspektiven und Kritik [The establishment of standards in teacher education. Theoretical perspectives and criticism]. Zeitschrift für Pädagogik [Journal of Education], 51 (2), 259-265 [in Germany].

Schützenmeister, J. (2002). Professionalisierung und Polyvalenz in der Lehrerausbildung [Professionalization and polyvalence in teacher education]. Marburg: Tectum Verlag DE [in Germany].

Terhart, E. (2000). Perspektiven der Lehrerbildung in Deutschland [Perspectives of Teacher Education in Germany]. Abschlußbericht der von der Kultusministerkonferenz eingesetzten Kommission. Weinheim: Beltz [in Germany].

Therhart, E. (2005). Standards für die Lehrerbildung - ein Kommentar [Standards for teacher education a comment]. Zeitschrift für Pädagogik [Journal of Education], 51 (2), 275-279 [in Germany]

Людмила Дяченко, кандидат педагогічних наук, старший науковий співробітник відділу зарубіжних систем педагогічної освіти і освіти дорослих Інституту педагогічної освіти і освіти дорослих імені Івана Зязюна Національної академії педагогічних наук України.

Liudmyla Diachenko, PhD in Pedagogy, Senior Researcher of the Department of Foreign Systems on Pedagogical Education and Adult Education, Ivan Ziaziun Institute of Pedagogical Education and Adult Education of NAES of Ukraine.

E-mail: diachenko.lm@gmail.com ORCID ID 0000-0001-6897-124X 